Annals of Warsaw University of Life Sciences - SGGW

Land Reclamation No 49 (4), 2017: 301-314

(Ann. Warsaw Univ. of Life Sci. - SGGW, Land Reclam. 49 (4), 2017)

\title{
Analysis of ice phenomena hazard on the middle Odra river
}

\author{
KRZYSZTOF WOLSKI ${ }^{1}$, TOMASZ TYMIŃSKI ${ }^{1}$, BEATA GŁUCHOWSKA ${ }^{2}$ \\ ${ }^{1}$ Faculty of Environmental Engineering and Geodesy, Wroclaw University of Environmental and Life \\ Sciences \\ ${ }^{2}$ Regional Water Management Authority in Wroclaw
}

\begin{abstract}
Analysis of ice phenomena hazard on the middle Odra river. The paper contains analysis of ice phenomena occurrence in the light of recent observations conducted on middle Odra river from Krapkowice (ca. $\mathrm{km} \mathrm{125+000)}$ to Krosno Odrzańskie (ca. km 530+000). In detail the research embraced time of occurrence and intensity of individual ice phenomena in years 2006-2017 together with reference and comparison of data to previous data from period 1957-2005 . In characteristic cross-sections there is a reference to occurrence of all observed forms of ice phenomena (frazil ice, border ice, ice cover, floe and ice-jam). In the study a reference data of Regional Water Management Authority in Wrocław were used together with results of previous research conducted at the Wrockaw University of Environmental and Life Sciences. The results legitimized, that the occurrence of ice phenomena on middle Odra river has time of its appearance, duration and intensity and is not stable in every year. Occurrence of ice phenomena on middle Odra river varies in time, being observed as manifold forms of icing - most frequently border ice and frazil ice. During the last 12 years greater than the average number of days with ice phenomena occurrence can be observed, but these phenomena have definitely "milder" character (border ice).
\end{abstract}

Key words: ice phenomena, frazil ice, border ice, ice cover, ice-jam, Odra river

\section{INTRODUCTION}

A characteristic of ice phenomena is very problematic for a number of reasons. There is a lack of uniform classification of phenomena in rivers, which leads to existence of wide margins in used terminology (Mokwa and Tymiński 2013). Monitoring of ice phenomena causes significant difficulties. Ice phenomena often have local character, however essential in terms of watercourse hydraulics, but imperceptible on respective surveillance outposts. Observations are usually conducted by object administrators (in particular the Regional Water Management Authority) and by hydrologic surveillance service of the Institute of Meteorology and Water Management - National Research Institute (IMWM-NRI). Though ice phenomena measurements are difficult to conduct and often their results are subjective to given observer, frequently represented in descriptive form. Largely they are conducted as an operational monitoring of aforementioned services in order to exercise control and to carry out activities in the matters of flood protection, counteraction to river blockage events, exploitation of water structures 
and other. All of this have an impact on accuracy and interpretation of ice phenomena measurements results, which are available with difficulty and often useless for scientific considerations due to the practical aspect of measurements. The complexity of physical processes progressing in time of formation, existence and disappearance of ice phenomena, as well as their mathematical description, cause great difficulties (IMGW 2015).

Research on occurrence of ice phenomena are not conducted all over the world. This is a consequence of the fact that occurrence of ice in rivers can be observed only in some of geographical latitudes. Main research is conducted in USA and Canada (Ashton 1978, 1986, Shen 1996, 2003, Beltaos 2009), Central and Northern Europe (Matousek 1984, Kokkonen and Leppäranta 2013, Takács and Kern 2015, Lindenschmidt 2017), Russia (Vuglinsky 2002, Frolova et al. 2011, Agafonova et al. 2017) and China (Fu et al.2014). Numerous research refers also to subjects that are not brought up in this paper - thermal and occurrence of ice phenomena on lakes and reservoirs, where ice-formation process is less dynamical, and also important.

In Poland the subject of ice phenomena was studied in several centers, in terms of various rivers (Gołek 1957, Lambor 1959, Gołek 1964, Pasławski 1970, Grześ 1991, 1999, Majewski 1997, 2009, Kolerski 1999). On middle Odra river analyses and descriptions of ice phenomena were handled for, i.a.: Wrocław hydrosystem - Rogala and Machajski (PWR Raport 1998, Rogala and Machajski 2000), whilst comprehensively for river section from Olawa to Brzeg Dolny - Mokwa's research team (Mokwa
2006), with special consideration of the Wrocław Waterway Junction (Mokwa and Tymiński 2013). Previous research, pictured in literature, is limited to period of year 2006 for middle Odra river and to year 2010 for Wrocław hydrosystem. This publication presents results of research, which is, to a certain extent, a continuation of abovementioned works and refers to the results of previous observations. There is no doubt, that the occurrence of ice phenomena causes change in the flow resistance as well as the reduction of effective cross-section, which leads to changes of flows at the same water level (Majewski 2009, Kolerski 2016).

The formation of ice is a result of continuously ongoing processes of heat exchange, mainly between air and water, but also soil under water and water. Factors that influence ice phenomena forms and intensity of their formation can be divided into:

- meteorological: temperatures of air and water, solar radiation, air humidity, wind, pressure, precipitation;

- hydraulic: watercourse downslope, velocity of flow, depth, velocity of vertical mixing;

- topographical: shape of riverbed and river valley, absolute height, type of the substrate, land use;

- anthropogenic: human activity, impact of sanitary fittings energy-related installations, regulations connected with formation of ice phenomena.

Figure 1 shows the formation of ice phenomena process during the whole season from autumn to winter (Shen 1996, 2003, Kolerski 2016).

Among ice forms that occur in Poland most frequently there can be distinguished (Mokwa and Tymiński 2013): 


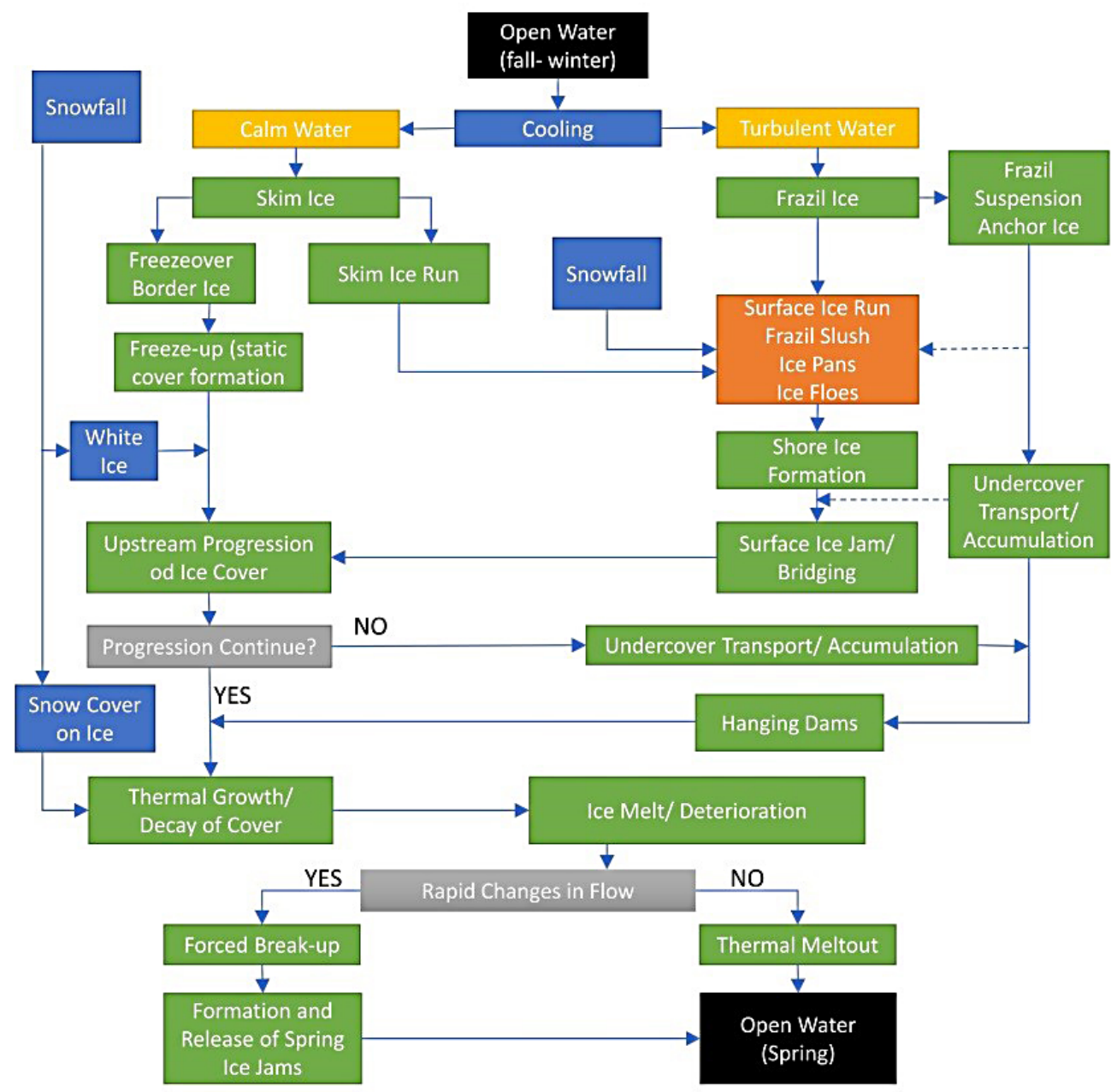

FIGURE 1. River ice process (Shen 1996, 2003, Kolerski 2016)

- anchor ice - forms on a water surface when supercooled water, because of its greater density, falls to the bottom and thanks to the presence of many stable particles - so-called condensation nuclei - freezes forming spongy heap; anchor ice can, apart from ice, contain material from bottom of river, i.a. plants or debris, even in the form of big stones;
- border ice (fast-shore ice) - superficial ice that forms ashore, at first in the form of ice glaze, then as a homogeneous ice cover that reaches, in the course of icing progress, to the middle of the river; - cladding - accumulation of frazil or anchor ice under the dense ice cover, often leading to limitation of riverbed cross-section capacity which causes jam; 
- floe - parts of cracked ice cover floating downstream;

- frazil ice - spongy ice that forms in the mass of water and surfaces afterwards;

- frazil ice discs - characteristic round ice forms with a diameter up to $3 \mathrm{~m}$ and thickness up to $1 \mathrm{~m}$, slightly elevated above the water table; their shape is an effect of rotation and constant collisions between them;

- frazil jam - a blockage of river cross-section by frazil ice at the time of freezing or, which is more often, by frazil cluster after the forming of ice cover; mass of frazil, thanks to its spongy construction, undergo aggregation and often reach to the bottom, which makes it impossible for water to flow in the cross-section;

- ice cover - immobile ice coat with smooth or irregular surface that covers the water table of river wholly or partially; on to of ice cover a snow or water can occur;

- ice jam - accumulation of floe in the riverbed at the time of ice progress that causes depletion of riverbed cross-section and water damming associated with it;

- needle ice - ice crystals suspended in water in the form of delicate needles or ice plates;

- polynya (ice rise) - surfaces of free water table in the ice cover; occurrence of this phenomenon in this paper was defined also as ice with gaps;

- water on ice - water on ice cover, which can origin from melting snow that lies atop of ice cover, flow of meltwater or outflow from under the ice cover.

\section{MATERIAL AND METHODS}

Daily observation data used for the research were acquired form 12 stations located along central Odra river from Krapkowice $\mathrm{km} 125+000$ to Krosno Odrzańskie km 530+000 (Central Odra Water Region):

- Krapkowice - km 125+000;

- Opole - km 147+000;

- Ujście Nysy - km 181+000;

- Wrocław - km 243+500;

- Brzeg Dolny - km 284+000;

- Malczyce - km 305+000;

- Ścianawa - km 332+000;

- Głogów - km 393+000;

- Nowa Sól - km 430+000;

- Cigacice - km 471+000;

- Nietków - km 491+000;

- Połęcko - km 530+000.

The location of surveillance outposts within the borders of water region is presented on Figure 2. A dense distribution of observations results from the fact that the ice phenomena vary in time and space.

In the paper data of Regional Water Management Authority in Wrocław were used (RZGW Wrocław 2011). These were reference data and information from bulletins available on authority's website. Based on collected data, the diagrams were created depicting occurrence of ice phenomena during years 2006-2017. Diagrams show pentadic periods (fiveday), therefore for period from November to March, 24 stages exist with ice phenomena detected. Occurring phenomena were classified into nine types (seven independently occurring phenomena: ice cover, ice with break, border ice, frazil ice, floe, water on ice, ice jam and two 


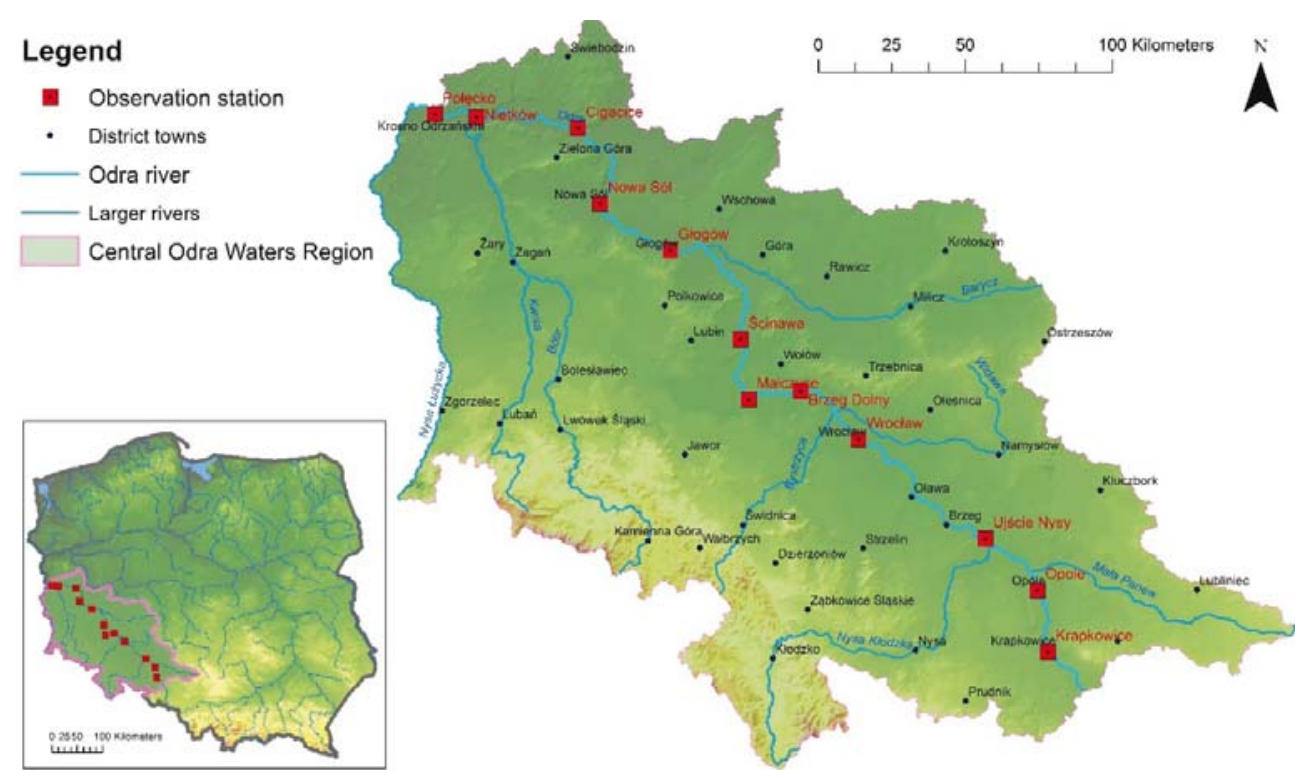

FIGURE 2. Location of the observation station on the background Central Odra Waters Region

mixed types: border ice/frazil and border ice/floe). It was assumed that one day of phenomenon occurrence during pentad is enough to acknowledge the whole pentad as a period of phenomenon duration. If within one pentad occurred more than one phenomenon, the longest one was noted as legitimate.

\section{RESULTS AND DISCUSSION}

Data prepared in pentadic periods were analyzed paying special attention to number of days with given form of ice phenomenon, dates of its occurrence and disappearance. Characteristics of observed ice phenomena occurrence are presented on diagrams on Figures 3, 4 and 5 .

Significant diversity in periods of ice phenomena occurrences on middle Odra river is noticeable on foregoing diagrams.
In the analyzed period there are years with ice phenomena occurring in nearly 3 months during the year $(2006,2010)$, and there are years without observed ice phenomena $(2007,2015)$. Moreover, years with ice phenomena occurred continuously $(2006,2008,2009$, and 2014) or were intermitted by periods with no ice phenomena (2010, 2011, and 2016). Early winter icing also occurred (2012, 2013), after which there was no ice phenomena, and main icing followed after a few pentads. Period of occurrence and disappearance of various icing forms is diversified in respective years, but generally it is similar on the middle Odra river section.

Structure of ice phenomena forms occurring on respective stations is presented on Figure 6 and the Table. Among the forms of ice phenomena on the majority of stations there is a 

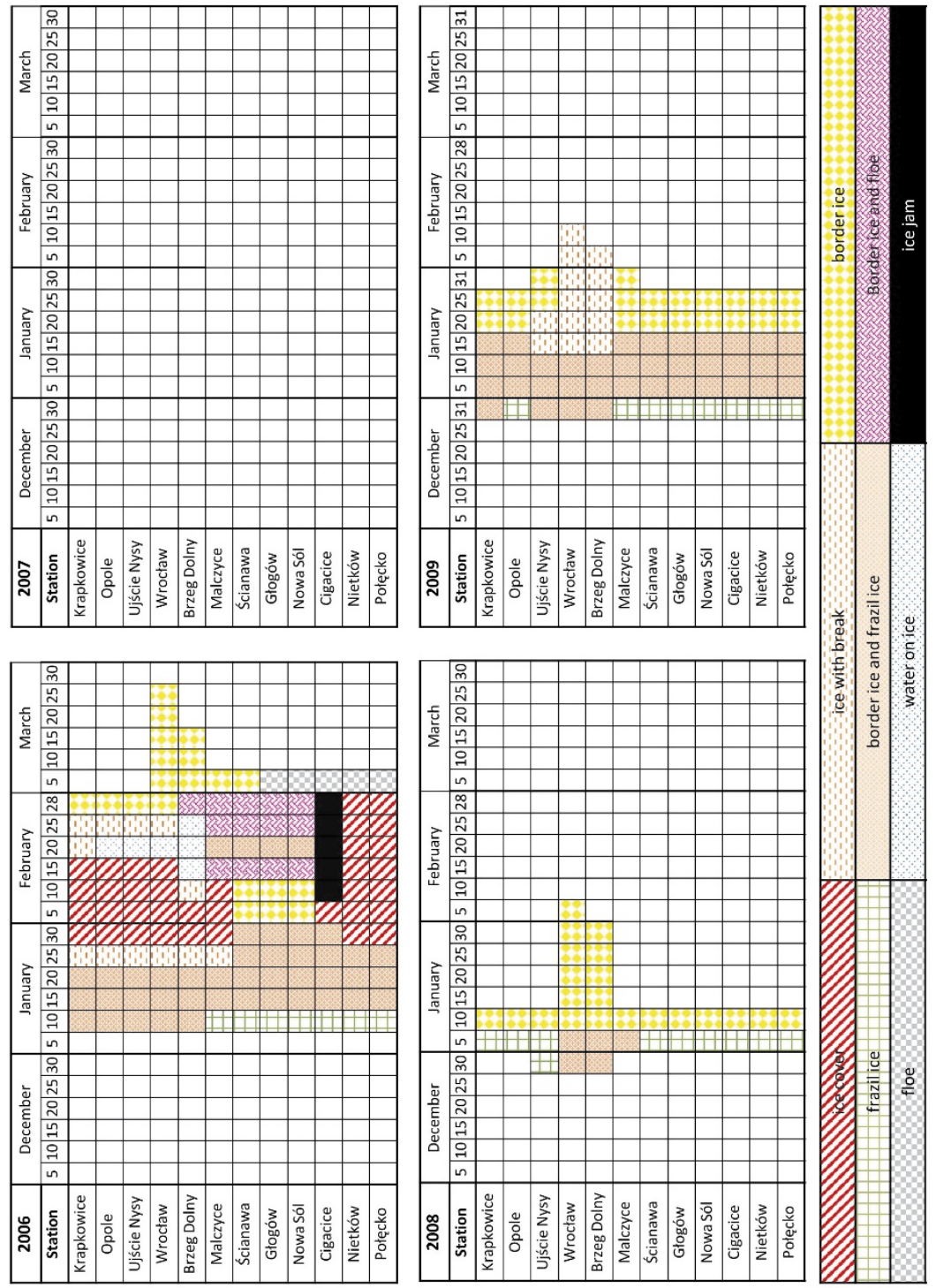

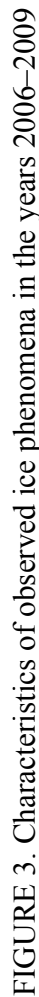



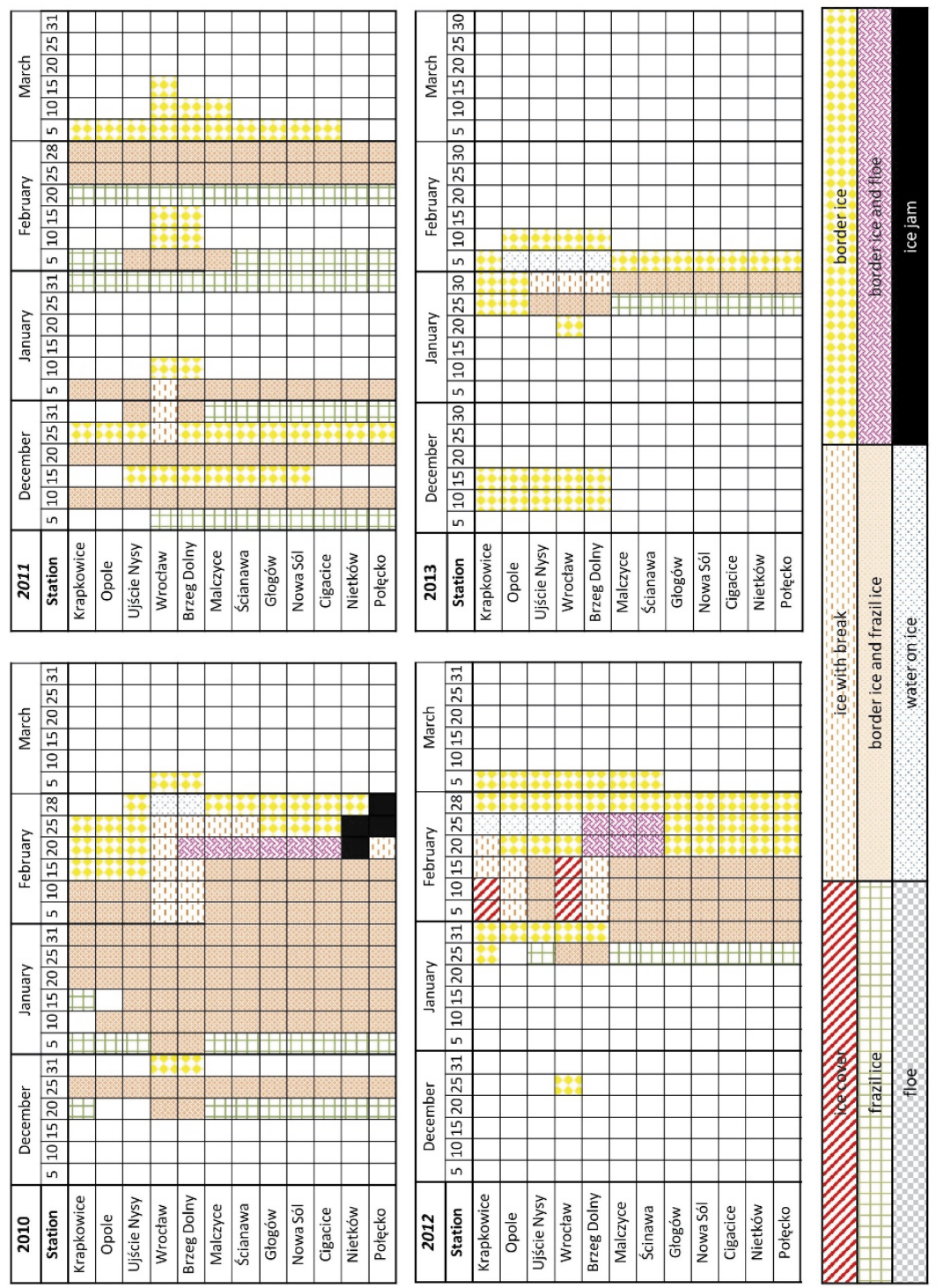

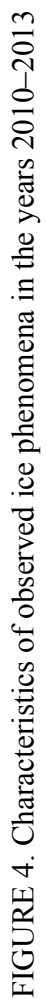



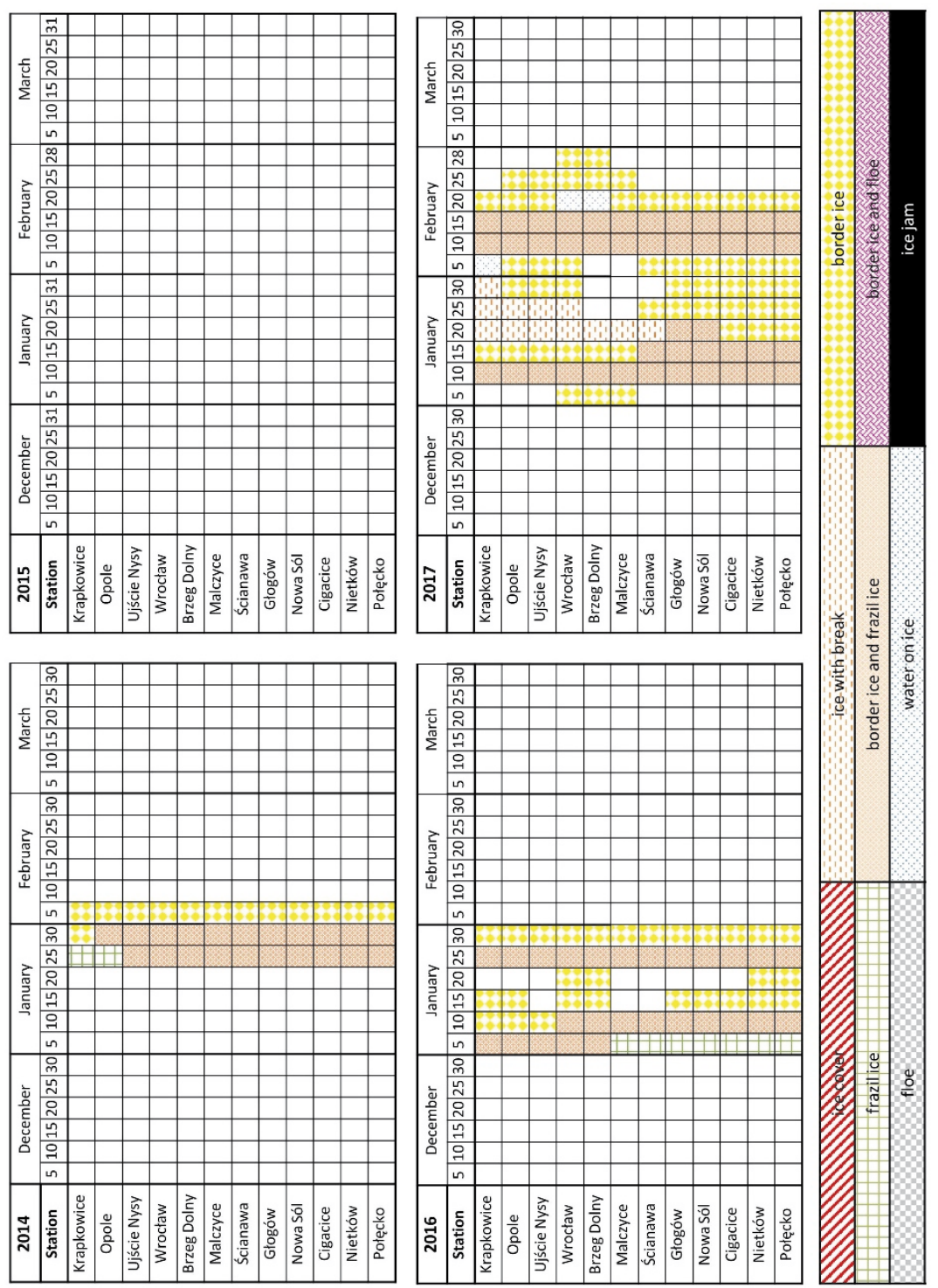

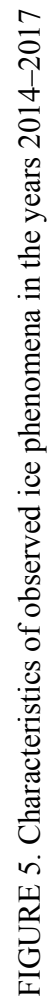
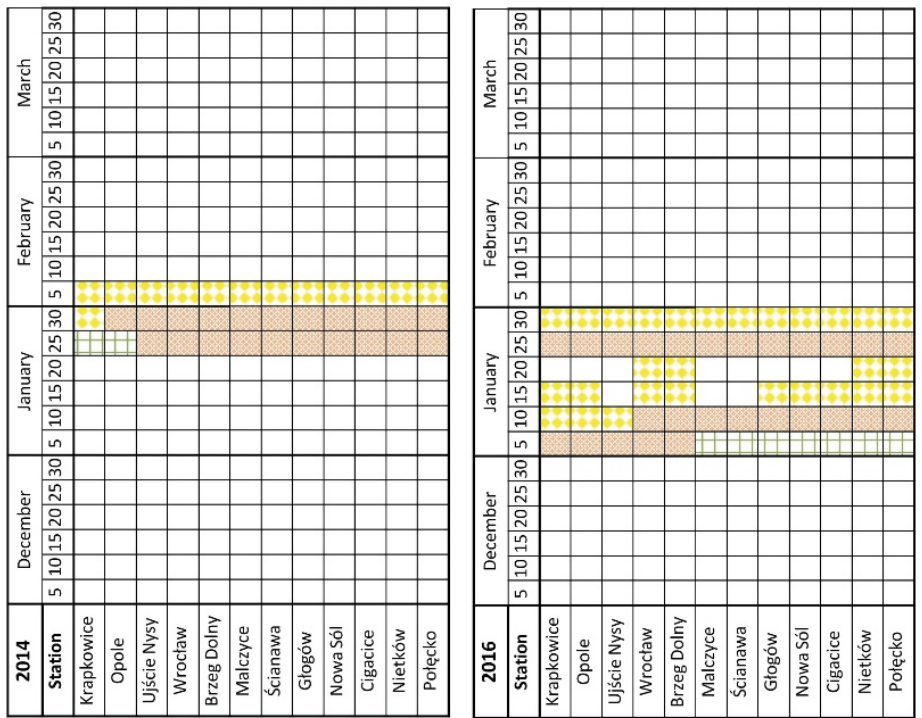


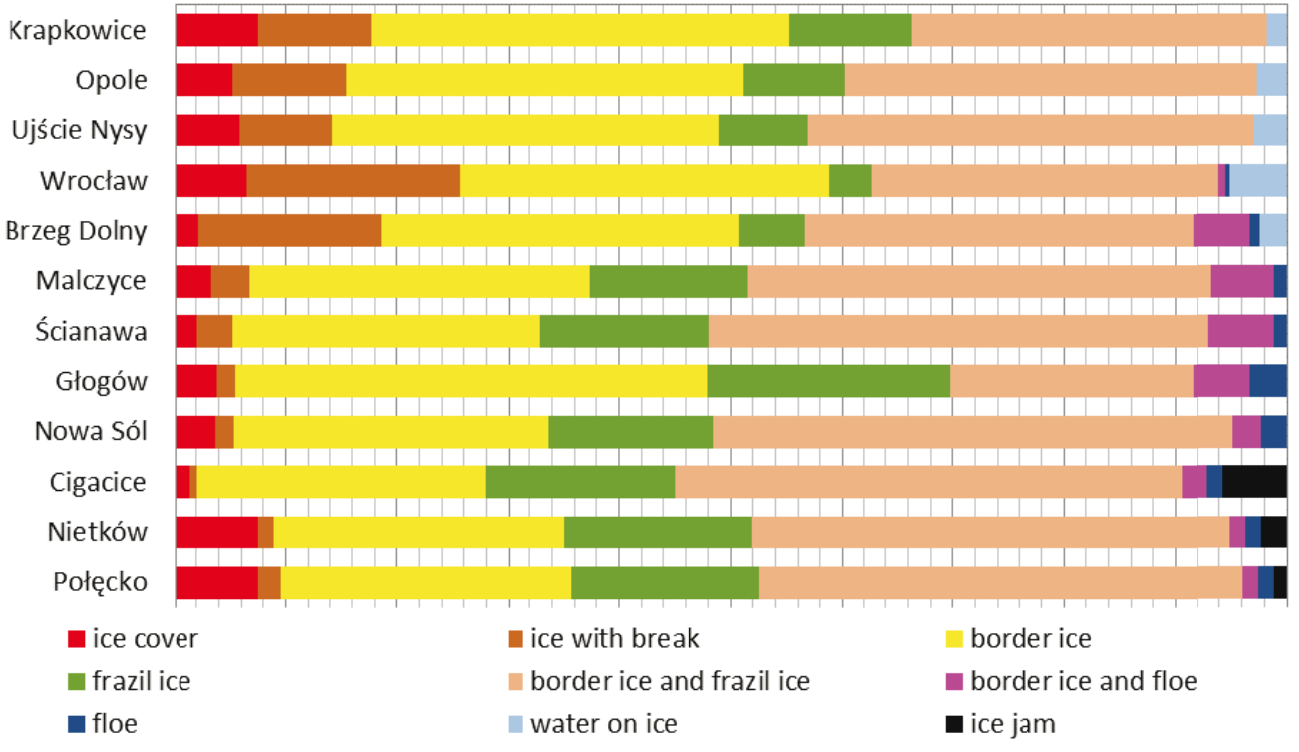

FIGURE 6. Frequency of occurrence of forms of ice phenomena in the years 2006-2017 along the central Odra river

TABLE. Frequency of occurrence of forms of ice phenomena in the years 2006-2017 along the central Odra river

\begin{tabular}{|c|c|c|c|c|c|c|c|c|c|}
\hline \multirow{2}{*}{ 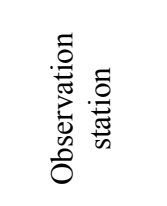 } & \multicolumn{9}{|c|}{ Forms of ice phenomena in $\%$ of occurrence time } \\
\hline & $\begin{array}{l}\dot{0} \\
0 \\
0 \\
.0\end{array}$ & 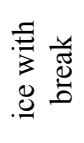 & 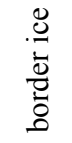 & 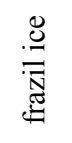 & 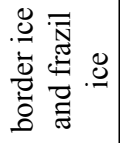 & 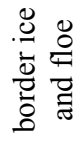 & $\stackrel{0}{\stackrel{0}{C}}$ & 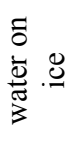 & 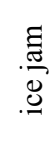 \\
\hline Krapkowice & 7.5 & 10.2 & 37.5 & 11.1 & 31.8 & 0.0 & 0.0 & 1.8 & 0.0 \\
\hline Opole & 5.2 & 10.2 & 35.8 & 9.0 & 37.2 & 0.0 & 0.0 & 2.6 & 0.0 \\
\hline Ujście Nysy & 5.9 & 8.3 & 34.8 & 8.0 & 40.1 & 0.0 & 0.0 & 2.9 & 0.0 \\
\hline Wrocław & 6.5 & 19.1 & 33.2 & 3.9 & 31.2 & 0.6 & 0.4 & 5.1 & 0.0 \\
\hline Brzeg Dolny & 2.2 & 16.5 & 32.1 & 5.9 & 34.9 & 5.2 & 0.9 & 2.4 & 0.0 \\
\hline Malczyce & 3.3 & 3.5 & 30.5 & 14.2 & 41.7 & 5.7 & 1.1 & 0.0 & 0.0 \\
\hline Ścianawa & 2.0 & 3.2 & 27.7 & 15.2 & 44.9 & 5.8 & 1.2 & 0.0 & 0.0 \\
\hline Głogów & 2.6 & 1.1 & 28.8 & 14.8 & 14.8 & 3.4 & 2.3 & 0.0 & 0.0 \\
\hline Nowa Sól & 3.7 & 1.7 & 28.2 & 14.8 & 46.7 & 2.6 & 2.3 & 0.0 & 0.0 \\
\hline Cigacice & 1.4 & 0.6 & 25.9 & 17.1 & 45.6 & 2.3 & 1.4 & 0.0 & 5.7 \\
\hline Nietków & 7.6 & 1.4 & 26.1 & 16.9 & 43.0 & 1.4 & 1.4 & 0.0 & 2.2 \\
\hline Połęcko & 7.6 & 2.0 & 26.1 & 16.9 & 43.5 & 1.4 & 1.4 & 0.0 & 1.1 \\
\hline
\end{tabular}


dominance of border ice (25.9-37.5\%) and border ice with frazil ice (14.8$-46.7 \%$ ) observations. On stations situated higher (Krapkowice, Opole, Ujście Nysy, Wrocław, Brzeg Dolny) there is a noticeably greater contribution of ice cover and ice cover with break (in total $14.2-25.6 \%)$ than on stations located lower (Malczyce, Ścinawa, Głogów, Nowa Sól, Cigacice, Nietków, Połęcko) $(2.0-9.6 \%)$. By contrast, in case of frazil ice dependence is opposite, where on lower section phenomenon occurs more often $(14.2-17.1 \%)$ than on upper section (3.9-11.1\%). Floe and border ice with floe occurred only on lower section from Wrocław to Połęcko, and their contribution on respective stations ranged from 1.0 to $7.7 \%$ of all ice phenomena. Similarly, ice jam occurred only on stations located lowest in the course of the Odra river and equaled $1.1 \%$ on station Połęcko, $2.2 \%$ on station Nietków and $5.7 \%$ on station Cigacice. Water on ice phenomenon occurred only on upper section (from Krapkowice to Brzeg Dolny) and equaled, on respective stations, $1.8-5.1 \%$ of all ice phenomena.
Along the middle Odra river three sections with similar characteristics of ice cover forming can be distinguished. On Figure 7, maximal, minimal and average, in period 2006-2017, numbers of days with ice phenomena are shown. Minimal value is 0 and is equal for all stations, because during multiannual period there were years with no ice phenomena occurrence on whole analyzed section of Odra river.

Upper section (Krapkowice, Opole and Ujście Nysy) can be characterized by relatively small amount of days with ice phenomena, ranging from 28.3 to 29.2 days per year. Maximal number of days with ice phenomena is also lowest there and range from 60 to 67 days. On the middle section (Wrocław, Brzeg Dolny) average number of days with ice phenomena is highest across the middle Odra river and reaches from 39.2 to 42 days in a year. Similarly, maximal number of days with ice phenomena is the highest here and equals 84 days. On the lower section of Odra river (from Malczyce to Połęcko) average number of days with ice phenomena varies from 29.4 to

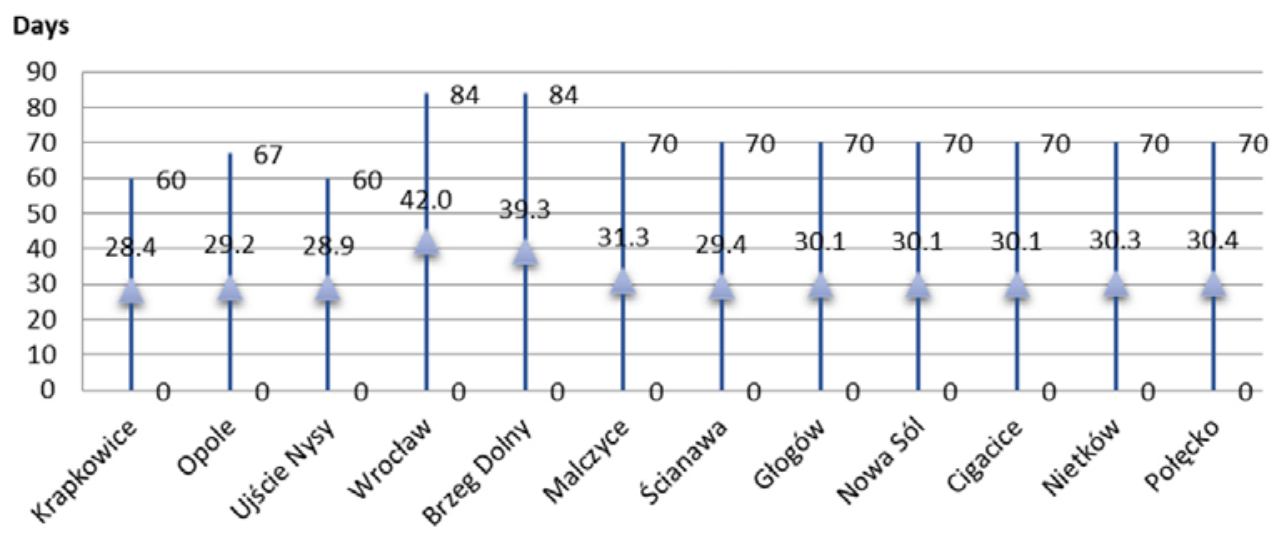

FIGURE 7. Minimum, maximum and average values of days with ice phenomena along the central Odra river 
31.3 days per year. Maximal values reach 70 days in a year with ice phenomena on this river section. Such diversification is caused by hydraulic characteristic of Odra river and by occurrence of dams. On the upper section downslopes are comparatively the largest, so relatively the water flows faster, its turbulence is more intensive and as a result the ice forming processes are obstructed. By contrast, on the middle section, many dams occur (Wrocław Waterway Junction), which reduce longitudal drop of river, causing water stagnation and diminution in turbulence. In such conditions ice phenomena are more likely to occur.

Results of observations conducted in Wrocław and data derived from previous research - since year 1958 - (Mokwa 2006, Mokwa and Tymiński 2013) is presented on Figure 8. In the analyzed multiannual period 1958-2017, the significant diversity is noticeable in number of days with ice phenomena occurrence. Maximal number of days with observed ice phenomena was 98 in year 1971. In the period 1958-2017 5 years without occurrence of ice phenomena were observed. Average number of days with ice phenomena in Wrocław in the period of 1958-2017 equaled 32 days (in years 2006-2017 - 42 days). Delimited linear trend relationship for the whole period from 1958 to 2017 indicates the minor decline in number of days with ice phenomena. However the most distinctive for whole period is very strong fluctuation in number of days with ice phenomena, without any significant tendencies to occurrence of periods of years with intensive as well as less intensive ice phenomena.

\section{CONCLUSIONS}

Occurrence of ice phenomena on the middle section of Odra river vary in time and space. Phenomena, which are often important from a practical point of view, are not analyzed in detail. Complexity of processes of forming, existence and disappearance of ice on river makes it nearly impossible to formulate simple dependencies and relationships between single factors that influence the appearance of ice and the ice phenomena alone. In the analyzed period of 2006-2017 various ice forms were observed on 12 surveillance outposts located along the middle section of Odra river. This made it possible to draw following conclusions:

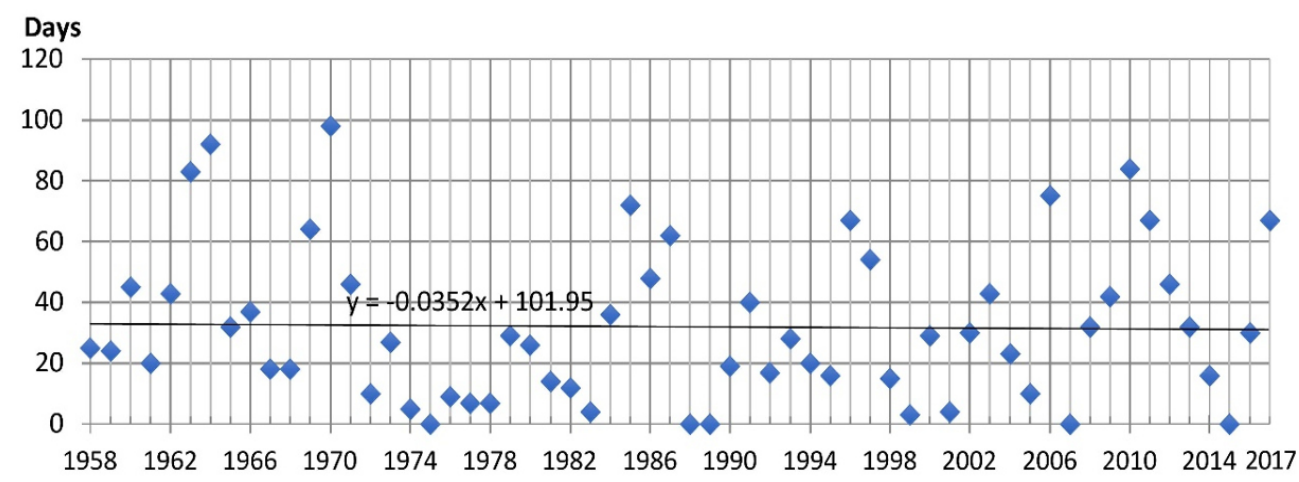

FIGURE 8. Average number of days per year with ice phenomena in Wrocław in 1958-2017 
1. Observations of ice phenomena are associated with strong subjectivity and uncertainty. For this reasons, from 12 characteristic ice phenomena types, 9 with highest frequency of occurrence were included in analysis.

2. Occurrence of ice phenomena on middle Odra river varies in time.

3. Many forms of icing occur, most frequently border ice, frazil ice and ice cover.

4. In the last 12 years observed number of days with ice phenomena is greater than the average from period 1958-2017 , but these phenomena are of less intensity (border ice and frazil instead of ice cover).

5. General trend from period 1958-2017 indicates the reduction of number of days with ice phenomena, which is in accordance with research conducted for other rivers in Poland (Pawłowski 2008, Pawłowski 2009, Gorączko 2013, Kornaś 2014, Pawłowski 2015, Bączyk and Suchożebrski 2016, Łukaszewicz and Jewgiel 2016, Ptak and Choiński 2016).

\section{Acknowledgments}

Authors would like to thank The Regional Water Management Authority in Wrocław for giving the access to data and materials that were essential for this publication.

\section{REFERENCES}

AGAFONOVA S.A., FROLOVA N.L., KRYLENKO I.N. et al. 2017: Dangerous ice phenomena on the lowland rivers of European Russia. Natural Hazards 88 (Suppl. 1), 171. https://doi.org/10.1007/s11069-016-2580-x.

ASHTON G.D. 1978: River ice. Ann. Rev. Fluid Mech. 10, 369-392.
ASHTON G.D. (Ed.) 1986: River and lake ice engineering. Water Resources, Littleton.

BĄCZYK A., SUCHOŻEBRSKI J. 2016: Zmienność przebiegu zjawisk lodowych na Bugu w latach 1903-2012 [Variability of ice phenomena on the Bug river in 1903-2012]. Ecol. Eng. 49, 136-142.

BELTAOS P., PROWSE T. 2009: River-ice hydrology in a shrinking cryosphere. Hydrol. Proc. 23 (1), 122-144.

FROLOVA N., AGAFONOVA S., NESTERENKO D. 2011: Water and ice regimes of the rivers of European Russia under climate change. Proceedings of symposium Hydro-climatology: Variability and Change (J-H02) held during IUGG2011 in Melbourne, Australia, July 2011. IAHS Publ. 344.

FU C., POPESCU I., WANG C., MYNETT A.E., ZHANG F. 2014: Challenges in modelling river flow and ice regime on the Ningxia-Inner Mongolia reach of the Yellow River, China. Hydrol. Earth Syst. Sci. 18, 1225-1237. https:// doi.org/10.5194/hess-18-1225-2014.

GOŁEK J. 1957: Zjawiska lodowe na rzekach polskich [Ice phenomena on Polish rivers]. Prace Państw. Inst. Hydr-Meteo. 48.

GOŁEK J. 1964: Zlodzenie rzek polskich [Ice formation of Polish rivers]. Prace Państw. Inst. Hydr-Meteo. 63.

GORĄCZKO M. 2013: Zmienność przebiegu zjawisk lodowych na Wiśle w rejonie Bydgoszczy [Variability of ice phenomena on the Vistula River in the vicinity of Bydgoszcz]. Sci. Rev. Eng. Env. Sci. 62, 382-388.

GRZEŚ M. 1991: Zatory i powodzie zatorowe na Dolnej Wiśle - mechanizmy i warunki [Ice jams and floods on the lower Vistula River]. IGiPZ PAN, Warszawa.

GRZEŚ M. 1999: Rola zjawisk lodowych w kształtowaniu koryta dolnej Wisły [Impact of ice phenomena on the riverbed of the Lower River]. Acta Universitatis Nicolai Copernici, Nauki Matematyczno-Przyrodnicze, Geografia 103, 113-128.

IMGW 2015: Pomiary i obserwacje hydrologiczne [Hydrological measurements and observations]. Instytut Meterologii i Gospodarki Wodnej, Warszawa.

KOKKONEN R., LEPPAERANTA M. 2013: River Kymijoki Ice Phenomena and Water Quality. 17th Workshop on River Ice, Edmonton. 
KOLERSKI T. 1999: Przepływ w korytach otwartych z pokrywą lodową [Flow in open channels with the ice cover]. XIX Ogólnopolska Szkoła Hydrauliki „Współczesne Problemy Hydrauliki Wód Śródlądowych". IBW PAN w Gdańsku, Gdańsk.

KOLERSKI T. 2016: Mathematical modeling of river ice process [Modelowanie matematyczne zjawisk lodowych na wodach śródlądowych]. IBN PAN w Gdańsku, Gdańsk.

KORNAŚ M. 2014: Ice phenomena in the Warta River in Poznań in 1961-2010. Quaestiones Geographicae 33 (1), 51-59. doi 10.2478/quageo-2014-0001.

LAMBOR J. 1959: Zjawiska lodowe na śródlądowych drogach wodnych w Polsce [Ice phenomena on the inland waterways in Poland]. Prace i Studia Kom. Gosp. Wodn. PAN, Prace Hydrol. 2, Part 1, 121-138.

LINDENSCHMIDT K.E., RIVICE A. 2017: NonProprietary, Open-Source, One-Dimensional River-Ice Model. Water 9, 314.

ŁUKASZEWICZ J., JAWGIEL K. 2016: Przebieg i charakter zjawisk lodowych na rzece Lebie [The course and the variability of ice phenomena on the Leba River]. Badania Fizjograficzne, Ser. A, 67, 99-117.

MAJEWSKI W. 1997: Powodzie zatorowe i sztormowe [Ice jam flooding and storm flooding]. XVII Ogólnopolska Szkoła Hydrauliki „Wspótczesne Problemy Hydrauliki Wód Śródladowych", IBW PAN w Gdańsku, Gdańsk.

MAJEWSKI W. 2009: Przepływy w korytach otwartych z uwzględnieniem zjawisk lodowych [Flow in open channels under the influence of ice phenomena]. IMGW, Warszawa.

MATOUSEK V. 1984: Types of ice runs and conditions for their formation. Proc. IAHR Ice Symposium, Hamburg.

MOKWA M. 2006: Zagrożenia wywołane zjawiskami lodowymi na skanalizowanym odcinku Odry od Oławy do Brzegu Dolnego [Risks caused by ice phenomena on the channelized Odra from Oława to Brzeg Dolny]. Zesz. Nauk. AR we Wrocławiu, Inż. Środ. 15, 534.

MOKWA M., TYMIŃSKI T. 2013: Zjawiska lodowe we Wrocławskim Węźle Wodnym [Ice phenomena in Wroclaw Waterway Junction]. [In:] T. Kałuża (Ed.). Hydrauliczne i hydrologiczne aspekty powodzi w 2010 roku w zlew- niach Wisły i Odry [Hydraulic and hydrological aspects of floods in the Vistula and Oder catchments in 2010]. Bogucki - Wydawnictwo Naukowe, Poznań.

PASŁAWSKI Z. 1970: Wpływ zjawisk lodowych na przepływ rzeczny [Influence of ice phenomena on river flow]. Prace PIHM 99.

PAWŁOWSKI B. 2008: Wieloletnia zmienność przebiegu zjawisk lodowych na Wiśle w Toruniu [Multiyear variability of ice phenomena on the Vistula River in Toruń]. Gospodarka Wodna 2, 49-53.

PAWŁOWSKI B. 2009: Long-term variability in the course of ice phenomena on the Vistula River in Toruń. Bull. Geograph. Phys. Geograph. Ser. 1, 91-102.

PAWŁOWSKI B. 2015: Determinants of change in the duration of ice phenomena on the Vistula River in Torun. J. Hydrol. Hydromech. 63, 2, 145-153.

PTAK M., CHOIŃSKI A. 2016: Ice phenomena in rivers of the coastal zone (Southern Baltic coastal zone) in the years 1956-2015. J. Ecol. Protect. Coastline 20, 73-83.

PWR Raport 1998: Analiza tworzenia się i likwidacji zatorów lodowych na rzece Odrze na terenie miasta i województwa wrocławskiego [Analysis of the formation and liquidation of ice jams on the Oder River in the city and province of Wroclaw]. Instytut Geotechniczny i Hydrotechniczny Politechniki Wrocławskiej, Wrocław [manuscript].

ROGALA R., MACHAJSKI J. 2000: Zjawiska lodowe na terenie Wrocławskiego Węzła Wodnego [Ice phenomena in Wroclaw Waterway Junction]. XX Ogólnopolska Szkoła Hydrauliki „Współczesne Problemy Hydrauliki Wód Śródlądowych”. IBW PAN w Gdańsku, Gdańsk.

RZGW Wrocław 2011: Obserwacje zjawisk lodowych na rzece Odrze w latach 1956-2010 [Observations of ice phenomena on the Odra river in 1956-2010]. Regionalny Zarząd Gospodarki Wodnej we Wrocławiu, Wrocław [manuscript].

SHEN H.T. 1996: River ice processes - State of research. Proceeding of 13th IAHR Symposium on Ice, Beijing 3, 825-833.

SHEN H.T. 2003: River Ice Research: Progress and Missing Links. 12th Workshop on the Hydraulics of Ice Covered Rivers, Edmonton. 
TAKÁCS K., KERN Z. 2015: Multidecadal changes in the river ice regime of the lower course of the River Drava since AD 1875. J. Hydrol. 529, 1890-1900.

VUGLINSKY V.S. 2002: Peculiarities of ice events in Russian Arctic rivers. Hydrol. Process. 16, 905-913.

Streszczenie: Analiza zagrożeń zjawiskami lodowymi na środkowej Odrze. W pracy zawarto analizę występowania zjawisk lodowych w świetle najnowszych obserwacji przeprowadzonych na środkowym odcinku Odry od Krapkowic (ok. km 125+000) do Krosna Odrzańskiego (ok. km $530+000)$. Szczegółowo badano czas występowania i intensywność poszczególnych zjawisk lodowych w latach 2006-2017 wraz z nawiązaniem i porównaniem tych danych do lat wcześniejszych - z okresu 1957-2005. W przekrojach charakterystycznych odniesiono się do występowania wszystkich zaobserwowanych form zjawisk lodowych (śryż, lód brzegowy, pokrywa lodowa, kra i zator). W pracy wykorzystano materiały źródłowe Regionalnego Zarządu Gospodarki Wodnej we Wrocławiu oraz wcześniejsze badania prowadzo- ne na Uniwersytecie Przyrodniczym we Wrocławiu. Uzyskane wyniki potwierdziły, że występowanie zjawisk lodowych na środkowej Odrze jest zjawiskiem, którego czas pojawiania się, okres trwania i intensywność nie są stałe w każdym roku. Występowanie zjawisk lodowych na środkowej Odrze jest zróżnicowane w czasie, przy czym spotkać tu można wielorakie formy zlodzenia - najczęściej lód brzegowy i śryż. W ostatnich 12 latach obserwuje się większą od przeciętnych liczbę dni ze zjawiskami lodowymi, lecz zjawiska te mają zdecydowanie „lżejszy” charakter (lód brzegowy).

\section{MS received November 2017}

\author{
Authors' address: \\ Krzysztof Wolski \\ Instytut Inżynierii Środowiska \\ Wydział Inżynierii Kształtowania Środowiska \\ i Geodezji \\ ul. Norwida 25, 50-375 Wrocław \\ Poland \\ e-mail: krzysztof.wolski@upwr.edu.pl
}

